\section{Özkan Ateș}

Sevim Öndül

Çağatay Önal

Mehmet Büyükkıraz

Hakan Somay

Süleyman R. Çayli

Mehmet A. Göğüsgeren

Metin Orakdöğen

Ayhan Koçak

Saim Yoloğlu

Zafer Berkman

Mahir Tevrüz

Published online: 2 September 2006

(C) Springer-Verlag 2006

\section{Post-traumatic early epilepsy in pediatric age group with emphasis on influential factors}

The online version of the original article can be found at: http://dx. doi.org/10.1007/s00381-005-1177-6.

Ö. Ateş $(\bowtie) \cdot$ Ç. Önal $\cdot$ S. R. Çayli $\cdot$ A. Koçak

Department of Neurosurgery, School of Medicine,

Turgut Özal Medical Center, Inönü University,

44069 Malatya, Turkey

e-mail: atesozkan@hotmail.com

Tel.: +90-422-3410669

Fax: $+90-422-3410738$

S. Öndül · M. Büyükkıraz · H. Somay · M. A. Göğüsgeren · M. Orakdöğen $\cdot$ Z. Berkman $\cdot$ M. Tevrüz

Department of Neurosurgery, Haydarpaşa Numune Hospital, Istanbul, Turkey

S. Yoloğlu

Department of Biostatistics,

Inönü University School of Medicine,

Malatya, Turkey

\section{Childs Nerv Syst (2006) 22:279-284}

Unfortunately, the article was published under the wrong section. The correct section should be "Original Paper". 